\title{
THERMAL STABILITY OF HIGH TEMPERATURE STRUCTURAL ALLOYS
}

C. E. Jordan, R.K. Rasefake, et. al

March 1999

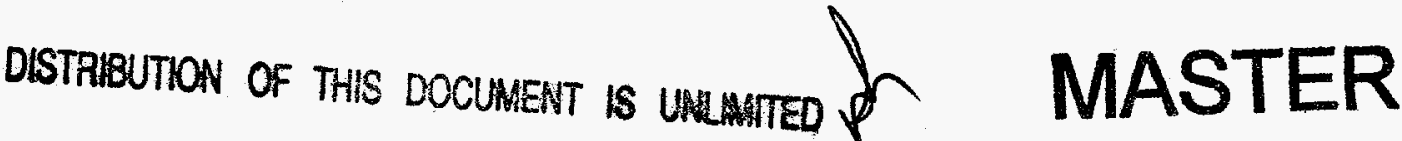

\section{NOTICE}

This report was prepared as an account of work sponsored by the United States Government. Neither the United States, nor the United States Department of Energy, nor any of their employees, nor any of their contractors, subcontractors, or their employees, makes any warranty, express or implied, or assumes any legal liability or responsibility for the accuracy, completeness or usefulness of any information, apparatus, product or process disclosed, or represents that its use would not infringe privately owned rights. 


\section{DISCLAIMER}

This report was prepared as an account of work sponsored by an agency of the United States Government. Neither the United States Government nor any agency thereof, nor any of their employees, make any warranty, express or implied, or assumes any legal liability or responsibility for the accuracy, completeness, or usefulness of any information, apparatus, product, or process disclosed, or represents that its use would not infringe privately owned rights. Reference herein to any specific commercial product, process, or service by trade name, trademark, manufacturer, or otherwise does not necessarily constitute or imply its endorsement, recommendation, or favoring by the United States Government or any agency thereof. The views and opinions of authors expressed herein do not necessarily state or reflect those of the United States Government or any agency thereof. 


\section{DISCLAIMER}

\section{Portions of this document may be illegible in electronic image products. Images are produced from the best available original document.}


Thermal Stability of High Temperature Structural Alloys

C.E. Jordan, R.K Rasefske, and A. Castagna

Lockheed Martin, Schenectady, NY 12301

\begin{abstract}
High temperature structural alloys were evaluated for suitability for long term operation at elevated temperatures. The effect of elevated temperature exposure on the microstructure and mechanical properties of a number of alloys was characterized. Fe-based alloys (330 stainless steel, $800 \mathrm{H}$, and mechanically alloyed MA 956), and Ni-based alloys (Hastelloy X, Haynes 230, Alloy 718, and mechanically alloyed MA 758) were evaluated for room temperature tensile and impact toughness properties after exposure at $750^{\circ} \mathrm{C}$ for 10,000 hours. Of the Fe-based alloys evaluated, 330 stainless steel and $800 \mathrm{H}$ showed secondary carbide $\left(\mathrm{M}_{23} \mathrm{C}_{6}\right)$ precipitation and a corresponding reduction in ductility and toughness as compared to the asreceived condition. Within the group of $\mathrm{Ni}$-based alloys tested, Alloy 718 showed the most dramatic structure change as it formed delta phase during 10,000 hours of exposure at $750^{\circ} \mathrm{C}$ with significant reductions in strength, ductility, and toughness. Haynes 230 and Hastelloy $X$ showed significant $\mathrm{M}_{23} \mathrm{C}_{6}$ carbide precipitation and a resulting reduction in ductility and toughness. Haynes 230 was also evaluated after 10,000 hours of exposure at 850,950 , and $1050^{\circ} \mathrm{C}$. For the $750-950^{\circ} \mathrm{C}$ exposures the $\mathrm{M}_{23} \mathrm{C}_{6}$ carbides in Haynes 230 coarsened. This resulted in large reductions in impact strength and ductility for the 750,850 and $950^{\circ} \mathrm{C}$ specimens. The $1050^{\circ} \mathrm{C}$ exposure specimens showed the resolution of $\mathrm{M}_{23} \mathrm{C}_{6}$ secondary carbides, and mechanical properties similar to the as-received solution annealed condition.
\end{abstract}

\title{
I. Introdüction
}

The alloys studied in this investigation, Fe-based alloys 330 stainless steel, $800 \mathrm{H}$, MA 956, and Ni-based alloys Hastelloy X, Haynes 230, Alloy 718, and MA 758 are some of the alloys considered suitable for elevated temperature applications. Material properties of interest included tensile strength, creep strength, toughness, fatigue resistance, environmental resistance, thermal stability, and others. Thermal stability is important as it indicates a material's ability to resist change in microstructure and critical properties during long-term exposure to high temperatures. Microstructural changes that can occur during thermal exposure include recrystallization, grain growth, change in the amount and distribution of phases, change in the morphology of phases present, and the formation of new phases. Therefore, the effect of elevated temperature exposure on microstructure and mechanical properties must be well characterized before a material is considered for use. The data reported here are tensile and impact properties after 10,000 hours of exposure at $750^{\circ} \mathrm{C}$. In addition, Haynes 230 was also evaluated after 10,000 hours of exposure at temperatures from $850^{\circ} \mathrm{C}$ to $1050^{\circ} \mathrm{C}$. 


\section{Experimental Procedure}

\section{Thermal Exposure}

Tables I and II list the chemical composition and initial heat treated condition of the alloys studied, respectively. Plate or flat samples of each of the materials were exposed in an air furnace at $750^{\circ} \mathrm{C}$ for 10,000 hours. Haynes 230 was also exposed at 850,950 , and $1050^{\circ} \mathrm{C}$ for 10,000 hours. Light optical microscopy was performed on mechanical test samples in both the as-received and thermally exposed conditions. Scanning electron microscopy (SEM) was performed on each of the thermally exposed samples, and Energy Dispersive X-ray Analysis (EDX) was performed to quantify the chemistry of the features observed in the microstructure. However, the chemical composition given by EDX analysis is not precise and should be considered as an estimate of the actual composition in the area analyzed.

\section{Tensile Testing}

Specimens were machined from the as-received and the thermally exposed material at a sufficient depth from the surface, such that surface oxidation would not influence testing results. Cylindrical threaded tensile specimens were machined from the longitudinal (parallel to rolling) direction. Generally, duplicate tensile tests were performed on the as-received material and the average value reported. Single tensile tests were performed on the thermally exposed material, unless noted otherwise. Tensile testing was conducted at room temperature according to ASTM E8, "Standard Methods for Tension Testing of Metallic Materials".

\section{Charpy Impact Testing}

Standard square cross sectional ( 0.395 in. $\times 0.395$ in.) Charpy specimens were machined from the asreceived and thermally exposed material in the longitudinal orientation, with the notch parallel to the short transverse direction. Unless otherwise noted, two Charpy tests were conducted in each condition and the average value reported. Testing was conducted at room temperature according to ASTM E23, "Standard Methods of Notched Bar Impact Testing of Metallic Materials".

\section{Results and Discussion}

\section{A. Fe-based Alloys}

\section{Microstructure}

a. 330 Stainless Steel

\section{As-Received Microstructure}

The 330 stainless steel consists of an austenite matrix with a mix of fine intergranular and intragranular chromium rich $\mathrm{M}_{23} \mathrm{C}_{6}$ carbides, as shown in Figure la. 
Post $750^{\circ} \mathrm{C} / 10,000 \mathrm{hr}$ Exposure Microstructure

The grain size of the alloy was essentially unchanged after exposure. The precipitation of fine intragranular carbides was observed, as well as the coarsening of intragranular carbides, and the formation of annealing twins (Figure 1b). Energy Dispersive X-ray (EDX) analysis indicated a matrix composition of $19.8 \mathrm{wt} \%$ $\mathrm{Cr}, 34.6 \mathrm{wt} \% \mathrm{Ni}, 1.1 \mathrm{wt} \% \mathrm{Si}$, and $2.25 \mathrm{wt} \% \mathrm{Mn}$; with no depletion of chromium in the matrix adjacent to the large carbide particles. This chemistry is similar to that reported in the as-received material, Table I.

\section{b. $800 \mathrm{H}$}

\section{As-Received Microstructure}

The $800 \mathrm{H}$ microstructure consists of an austenite matrix containing a mixture of coarse globular or blocky particles, characteristic of primary MC type titanium carbides and titanium nitrides, as well as fine particles, believed to be $\mathrm{M}_{23} \mathrm{C}_{6}$ carbides. The particles were dispersed intragranularly and to a lesser extent intergranularly. Annealing twins were also observed in the microstructure, as shown in Figure 2a.

\section{Post $750^{\circ} \mathrm{C} / 10,000 \mathrm{hr}$ Exposure Microstructure}

The microstructure after exposure contained a mixture of coarse primary carbides and intermediate to fine precipitated carbides dispersed both intra- and intergranularly and on twin boundaries. Secondary intragranular carbides were observed to preferentially precipitate around primary carbides and along preferred crystallographic directions, Figure $2 b$.

\section{c. MA956}

\section{As-Received Microstructure}

MA 956 contains an Fe-rich ferrite matrix with a fine dispersion of submicron sized intra- and intergranular yttrium-aluminum oxide particles, which are too fine to observe in light optical microscopy. The microstructure is highly directional and contains extremely large elongated grains when viewed in the longitudinal orientation. Also evident in the microstructure are micron sized intergranular particles, presumably oxide or carbide particles, as shown in a transverse orientation in Figure 3a.

Post $750^{\circ} \mathrm{C} / 10,000 \mathrm{hr}$ Exposure Microstructure

The post exposure microstructure is similar to that of the as-received material with some particle coarsening evident, Figure $3 \mathrm{~b}$.

\section{Mechanical Properties}

Table III shows mechanical properties of the Fe-based alloys before and after exposure at $750^{\circ} \mathrm{C} / 10,000$ hours. The 330 stainless steel showed a slight decrease in yield strength and percent reduction in area after 
exposure. Impact toughness was significantly reduced due to carbide precipitation, however, 330 stainless steel had the highest post exposure impact strength $(151.5 \mathrm{ft}-\mathrm{lb})$ of all of the Fe-based alloys studied.

$800 \mathrm{H}$ showed a slight increase in yield strength after exposure. The alloy lost toughness after exposure, most likely due to secondary carbide $\left(\mathrm{M}_{23} \mathrm{C}_{6}\right)$ precipitation and coarsening (Figure $2 \mathrm{~b}$ ).

MA 956 showed a slight increase in yield strength, but a reduction in ductility after exposure. The reduction in toughness is likely due to oxide or carbide particle coarsening. MA 956 had low impact strength both pre and post exposure. This alloy is known to have low room temperature toughness properties.

Both 330 stainless steel and $800 \mathrm{H}$ showed an increase in secondary $\mathrm{M}_{23} \mathrm{C}_{6}$ carbide precipitation due to exposure, with corresponding reductions in ductility and toughness. However, both alloys retained a fair amount of ductility and toughness. MA 956, as expected, had the lowest room temperature ductility and toughness in both the as-received and thermally exposed conditions. MA 956 impact toughness data also showed more variability, with a standard deviation of $5-7 \mathrm{ft}-\mathrm{lb}$ associated with the toughness values reported in Table III; therefore, quantifiable reductions in toughness and ductility were not as clear.

In summary, all of the Fe-based alloys studied showed post exposure reductions in ductility and toughness due to either carbide precipitation or coarsening of carbide or oxide particles. This precipitation and coarsening is likely the cause for reduced toughness in all of the alloys. The impact toughness tests were the most sensitive of the mechanical tests to thermal exposure. The data indicate that all of the Fe-based alloys became more notch sensitive after exposure.

\section{B. Ni-based Alloys}

\section{Microstructure}

\section{a. Hastelloy X}

As-Received Microstructure

Hastelloy $\mathrm{X}$ has a coarse grained austenite matrix microstructure, with many annealing twins. The microstructure also contains a mixture of coarse and fine primary carbides which were dispersed both intraand intergranularly, Figure $4 \mathrm{a}$.

\section{Post $750^{\circ} \mathrm{C} / 10,000 \mathrm{hr}$ Exposure Microstructure}

Post exposure a large amount of precipitation was noted in Hastelloy $\mathrm{X}$, as well as an increase in grain size (Figure 4b). Coarse precipitates were found to form intergranularly, while fine precipitates formed intragranularly along crystallographic planes. The coarse precipitates were analyzed by EDX and were 
found to be Mo-rich (20-25 wt\%), possibly $\mathrm{M}_{6} \mathrm{C}$ type carbides. The fine precipitates were $\mathrm{Cr}$-rich (35 wt\%), possibly $\mathrm{M}_{23} \mathrm{C}_{6}$ type carbides. The carbide type determination is based upon alloy chemistry and past characterization of these alloys by other investigators. The matrix was also found to be depleted in Mo (4.7 wt\% vs. $9.0 \mathrm{wt} \%$ nominal). Previous work on Hastelloy X [1] has shown that extensive precipitation of $\mathrm{M}_{23} \mathrm{C}_{6}$, as well as the $\mathrm{Cr}-\mathrm{Fe}$ sigma phase, occurs at 650 and $760^{\circ} \mathrm{C}$ after exposures of 1,000 hours. Extensive precipitation of secondary $\mathrm{M}_{23} \mathrm{C}_{6}$ carbides was noted in this study. However, no attempt was made to perform a higher resolution characterization of the microstructure to identify the formation of sigma phase.

\section{b. Haynes 230}

\section{As-Received Microstructure}

Haynes 230 unexposed microstructure consists of an austenite matrix that contains a uniform distribution of coarse intra- and intergranular precipitates which are most likely $\mathrm{M}_{6} \mathrm{C}$ type carbides. Fine intragranular precipitates are also present, and are most likely $\mathrm{M}_{23} \mathrm{C}_{6}$ type carbides, Figure $5 \mathrm{a}$.

\section{Post $750^{\circ} \mathrm{C} / 10,000 \mathrm{hr}$ Exposure Microstructure}

Post exposure, the Haynes 230 microstructure showed extensive precipitation of fine carbides along grain boundaries, most likely the $\mathrm{M}_{23} \mathrm{C}_{6}$ type, Figure $5 \mathrm{~b}$. Estimates of carbide type are based upon EDX analysis and known alloy history. The fine precipitates were somewhat coarser than that observed in the as-received material. EDX analysis of the large primary precipitates indicated that they were $\mathrm{W}$ and Mo rich, possibly $\mathrm{M}_{6} \mathrm{C}$ type carbides; and contained little $\mathrm{Cr}$, similar to the as-received microstructure. This observed microstructural change agrees with previously reported data that precipitation of secondary carbides occurs at exposures of $760^{\circ} \mathrm{C}[2]$.

\section{Post Exposure at 850,950 and $1050^{\circ} \mathrm{C}$}

At higher temperatures of exposure a morphology change was observed in the primary $\mathrm{M}_{6} \mathrm{C}$ carbides from a blocky to a more irregular shape. It was also observed that less intragranular carbides were present. Figure $5 \mathrm{c}$ shows the Haynes 230 microstructure after a $950^{\circ} \mathrm{C} / 10,000 \mathrm{hr}$ exposure. The $1050^{\circ} \mathrm{C}$ exposed specimens exhibited a microstructure similar to the as-received solution annealed condition.

\section{c. Alloy 718}

\section{As-Received Microstructure}

The as-received Alloy 718 microstructure was coarse grained with some annealing twins. It also contained intermediate and coarse sized inter- and intragranular carbides, Figure 6a. Alloy 718 is a precipitation strengthened alloy, containing $\gamma$ " and $\gamma$ 'precipitates, which are too fine in size to view in light optical microscopy. 
Post $750^{\circ} \mathrm{C} / 10,000 \mathrm{hr}$ Exposure Microstructure

Alloy 718 post exposure microstructure showed coarsening of some of the precipitates (possibly $\mathrm{M}_{6} \mathrm{C}$ type carbides), which were observed under higher magnification in the SEM. Extreme precipitation of a needlelike phase occurred throughout the material, Figure $6 \mathrm{~b}$. This phase is believed to be the orthorhombic delta phase, $\mathrm{Ni}_{3}(\mathrm{Nb}, \mathrm{Ti})$, that is commonly observed after extended exposure at this temperature [3-5].

The possible identification of delta phase is based upon alloy history and previous characterization of this alloy after thermal exposure. It has also been reported that as the percentage of delta phase formed increases, a transition from a $\gamma$ " dominated microstructure to a more mixed $\gamma " / \gamma$ ' phase distribution occurs [3]. Analyses of the $\gamma^{\prime \prime} / \gamma^{\prime}$ ratio were not conducted in this study.

\section{d. MA 758}

\section{As-Received Microstructure}

MA 758 is an austenite matrix that contains a fine dispersion of yttrium-aluminum oxide particles that are not visible in light optical microscopy. Some intermediate to fine precipitates were evident in the transverse orientation, Figure 7a. The microstructure is more equiaxed than MA 956, Figure 3a.

\section{Post $750^{\circ} \mathrm{C} / 10,000 \mathrm{hr}$ Exposure Microstructure}

The post exposure microstructure is similar to that of the as-received microstructure, Figure $7 \mathrm{~b}$.

\section{Mechanical Properties}

Table IV shows the mechanical properties of the Ni-based alloys pre and post thermal exposure. Of the Nibased alloys evaluated (Hastelloy X, Haynes 230, Alloy 718, and MA758), Hastelloy X and Alloy 718 showed significant precipitation of brittle phases due to exposure at $750^{\circ} \mathrm{C} / 10,000 \mathrm{hr}$, resulting in large reductions in ductility and toughness. Toughness values as low as $4.5 \mathrm{ft}-1 \mathrm{~b}$ were found for both of these materials after exposure.

Hastelloy X showed a slight increase in yield strength after exposure (Table IV), as well as a large drop in percent reduction of area (ductility). These property changes are believed to be due to the extensive $\mathrm{M}_{23} \mathrm{C}_{6}$ precipitation that occurred during exposure (Figure $4 \mathrm{~b}$ ), likely accompanied by sigma phase precipitation [1].

Alloy 718 showed the most significant effects of exposure on mechanical properties, presumably due to the formation of the topologically close packed (TCP) delta phase. A dramatic decrease in ultimate and yield strength, ductility, and impact toughness was observed for this alloy. These results were expected for long time exposures above $650^{\circ} \mathrm{C}[3]$. 
Haynes 230 after 10,000 hours of exposure at $750^{\circ} \mathrm{C}$ showed a small decrease in yield strength and reductions in ductility and impact toughness (Table IV), presumably due to secondary carbide precipitation and coarsening. In contrast, MA 758 showed relatively unchanged properties after exposure at $750^{\circ} \mathrm{C}$. Of the Ni-based alloys, MA 758 had the lowest as-received ductility and toughness, but showed the highest ductility and toughness after exposure.

Haynes 230 was also evaluated for 10,000 hours of exposure at 850,950 , and $1050^{\circ} \mathrm{C}$ (Table V). Impact toughness remained essentially unchanged as the temperature of exposure increased up to $950^{\circ} \mathrm{C}$. The most significant microstructural changes observed over this temperature range were: (1) a change in primary carbide morphology, and (2) a reduction in the amount of secondary intragranular $\mathrm{M}_{23} \mathrm{C}_{6}$ carbides. The exposed samples did not follow the expected trend of reduced ductility after exposure to progressively higher temperatures. The lowest value of ductility was observed after the $850^{\circ} \mathrm{C}$ exposure, as both the $950^{\circ} \mathrm{C}$ and $1050^{\circ} \mathrm{C}$ exposures showed higher ductility and toughness values. It appeared as though at $1050^{\circ} \mathrm{C}$ the secondary crabides had resolutionized. This microstructural observation is consistent with the $1050^{\circ} \mathrm{C}$ thermally exposed toughness and ductility values being similar to that of the initial as-received solution annealed condition. Note that the $1050^{\circ} \mathrm{C}$ data was collected from a different heat than that used for the other exposure temperatures.

In summary, Hastelloy X, Haynes 230, and Alloy 718 showed reductions in ductility and toughness after exposure. Hastelloy $\mathrm{X}$ and Alloy 718 showed significant microstructural changes after $750^{\circ} \mathrm{C} / 10,000$ hours of exposure, and the greatest degree of reductions in ductility and toughness. MA 758 showed little change in microstructure, slight reductions in strength, and no reductions in ductility or toughness. Although Haynes 230 showed an increase in secondary carbide precipitation, a fair amount of ductility was maintained after exposure at $750^{\circ} \mathrm{C}$. After exposures at 850,950 and $1050^{\circ} \mathrm{C}$ Haynes 230 retained a good amount of ductility and toughness.

The Fe-based alloys overall showed greater ductility and toughness after exposure as compared to the Nibased alloys. The Ni-based alloys Hastelloy $\mathrm{X}$ and Alloy 718 showed the formation of brittle intermetallic phases. Of the alloys evaluated, the alloys that exhibited the greatest retained ductility and toughness after exposure (in order of decreasing ductility and toughness) were 330 stainless steel, $800 \mathrm{H}, \mathrm{MA} 758$ and Haynes 230.

\section{Conclusions}

1. The Fe-based and Ni-based alloys evaluated for thermal stability in this study confirmed expected behavior based upon earlier work by other investigators conducted at shorter exposure times. 
2. The Fe-based alloys 330 stainless steel, $800 \mathrm{H}$, and MA 956 showed reductions in ductility and toughness after $750^{\circ} \mathrm{C} / 10,000 \mathrm{hr}$ exposure. Although carbide precipitation occurred in 330 stainless steel and $800 \mathrm{H}$, they retained a fair amount of toughness and ductility after moderate temperature exposure at $750^{\circ} \mathrm{C}$.

3. The Ni-based alloy MA 758 showed little change in ductility and toughness, after $750^{\circ} \mathrm{C} / 10,000$ hours of exposure. Haynes $\mathbf{2 3 0}$ showed more of a reduction in toughness. Therefore the relative stability of MA 758 microstructure, and the mechanical properties of Haynes 230 indicate that these alloys are also potential candidates for long-term use at $750^{\circ} \mathrm{C}$.

4. Haynes 230 exposed at 850 and $950^{\circ} \mathrm{C}$ exhibited adequate ductility and toughness properties for use within this temperature range.

5. After exposures up to $1050^{\circ} \mathrm{C}$, Haynes 230 exhibited a solution annealed condition in mechanical properties with retained ductility and toughness similar to that of the as-received solution annealed alloy.

\section{Acknowledgements}

The authors gratefully acknowledge the efforts of Fred Huemann for conducting the experimental exposures, and Bruce Furbek for conducting the mechanical testing associated with this thermal stability study.

\section{References}

1. H. M. Tawancy, Journal of Materials Science, 18, 1993, pp. 2976-2986.

2. D. L. Klarstrom, Corrosion 1994, NACE International, pp. 407/1-407/12.

3. J. F. Radavich, Superalloy 718 Metallurgy and Applications, TMS, 1989, pp. 257-268.

4. E. Guo, et. al., Superalloys 718, 625, 706 and Various Derivatives, TMS, 1991, pp. 397-408.

5. J.F. Radavich, 718, 625, 706 and Various Derivatives, TMS, 1997, pp. 409-415. 